\title{
Financial Failure Prediction Using Financial Ratios: An Empirical Application on the Saudi Stock Exchange
}

\author{
Roba Alothaim \\ MBA Student, College of Business and Economics, Qassim University, Saudi Arabia
}

\begin{abstract}
The objective of this research is to predict financial failure of few selected companies using financial ratios. In addition, the goal of this review is to look at the segregating power of monetary crisis utilizing the factors of the Altman's Z-score display and build up a reasonable model for Saudi Arabia, which could give detect ahead of time about the budgetary pain of companies. To build up the model the review has classified the chosen factors from year 2013 to 2016 two bad performing and two good performing companies. Multivariate Discriminant Analysis (MDA) has been utilized as the logical strategy and synchronous estimation technique used to enter the factors in the research. The results show that all the company's fall within the gray are, which indicates a weakness in performance and inability to make satisfactory profits for shareholders. Companies results reveal that most of them suffer from sever stagnation and that most of them do not distribute any profits at all or distribute very little profits. The two good performing companies continue to remain in the market while the two bad performers have quit the market.
\end{abstract}

Keywords: Financial ratios, Saudi Arabia, Stock Market

DOI: $10.7176 /$ RJFA/10-9-07

Publication date:May $31^{\text {st }} 2019$

\section{Introduction}

Is the attempt to predict the future position of the company and its financial viability and to know the extent of its potential risks. The forecasting process is the cornerstone of operations and planning operations. This can be done through forecasting the financial needs for operational completion and forecasting is a source of concern for financial analysts who choose to borrow finance and others. Predictability is a calculation to estimate potential future changes by examining the financial ratios that can be obtained through the established financial statements for this purpose. Investors utilize some modern models or depend on freely accessible information to procure an abnormal reward. Because of the unstable monetary conditions particularly in nations like Saudi Arabia, it is extremely hard to foresee the stock developments in the light of openly accessible information and those models. Therefore, it is imperative to recognize any appropriate option arrangement. Such sort of option is the utilization of financial ratios. Models that is competent to predict methods, bases and models through which accurate predictions can be obtained to reduce risk.

Altman's model is the most common and most widely used because of its ease of use. The Altman model is one of the most important models of predicting companies' failure because of its coping with the economies of the modern world and evolving.

Altman (1968) chose 33 bankrupt companies and 33 non-bankrupt question companies as tests amid the period from 1946 to the 1965 , and then he picked five from the underlying 22 monetary ratios and embraced the companies' information before they went investing liquidation and made a multi-bend work by utilizing disappointment. The Altman display tried in numerous countries. Each of these reviews to have inferred that Altman z-score model can foresee insolvency.

Monetary failure is characterized as the powerlessness of a firm to pay its commitments due to lack of working capital. At the end of the day, budgetary failure is the situation in which a firm goes bankrupt as a result of not having the capacity to meet its present liabilities. Firm that encounters money related failure cannot meet its commitments or experiences issues in satisfying its commitments in time. The case in which money streams could not meet the monetary commitments, the danger of budgetary failure also increases.

\section{The problem statement}

The problem of the study focuses on the seriousness of financial stumbling and its negative effects on the economies of countries and because of the increasing numbers of companies that have recently been affected and whose management is ignoring the status quo without a serious attempt to improve this situation. 
The main problem of the study is to shed light on the troubled companies and drew the attention of both current and future investors and corporate and stakeholder departments to reduce stumbling Financial losses as much as possible.

The use of financial ratios to analyze the financial statements helps the institution to know the status of the current institution and the future forecast, and because of the multiple uses of financial ratios, it is useful to know which of these ratios, which if used together can give accurate forecast of the companies before the failure of this stumbling time to help Companies to take appropriate action and possible solutions before it is too late.

\section{The scope of the study}

The data studied comprises of the annual financial statements of two non-failed firms and two failed firms in Saudi Arabia randomly selected for Four years spanning the period between 2013 - 2016.

\section{The relevance of the study}

The objective of this study is to highlight the distressed companies to reduce financial losses and avoid them as much as possible by applying the Altman model and determining the relative accuracy of the model predicting financial failure in time before failure, where the importance of the study is based on before taking enough time to capitalize on the prediction of failure Financial for industrial companies is required by decision-makers either from management, shareholders or stakeholders.

\section{Literature Review}

Altman et al (2014) the purpose of this paper is to review the literature on the importance of the Z-score model at the international level and its purpose in funding and other related areas. This review is based on an analysis of approximately 30 papers published in 2001 in leading accounting journals. The aim of the study was to evaluate the performance of the Z-"Score" model originally presented by Altman (1983). The model was originally applied to small, bankrupt US manufacturing companies. An amendment to the Z-Score of 1968 developed for listed manufacturers. The modified version can be used by private, industrial, and non-industrial companies. The analysis in this study shows that while a reasonably good international model works for most countries, with a forecast accuracy of approximately $70 \%$ the accuracy of the classification can be improved using the countryspecific assessment with the use of variables Add-ons. In some country models, the information provided by additional variables helps to boost the accuracy of the classification to a much higher level. In practice, it is clear that the generic version works well; however, the classification accuracy can be improved with country-specific versions.

Miller (2009) this paper examines common bankruptcy modeling and modeling models, the Altman Z-Score model based on the ratio of accounts, and the model of distance to default in a structured way. Z-Score's ranking is almost equal to the other two models when ranking relatively safe companies, which are illiquid when the probability of bankruptcy is high. All models have been found to have large type I errors by ranking a large number of companies that have not gone bankrupt as potentially dangerous. But the performance of the distance to the assumption was the best performance, the rating was higher before the bankruptcy, and the bankruptcy rate of the "safe" companies was higher than either of the other models. Of course, rating stability is important for creditors with regulatory requirements for credit quality. The distance to the default estimates was more volatile than both the Z-Score and the TLTA model. This is an intuitive result because "distance to default" relies more on market-based inputs, and market-based inputs are always more volatile than accounting-based inputs.

Hayes et al. (2010) in this study, the researcher examined the effectiveness of Altman's Z in predicting financial distress in retail establishments. In eight comparisons, four of which in 2007 and 2008, of bankrupt companies versus non-bankrupt retail stores, "Z" predicted the accuracy of bankruptcy by $94 \%$ of the time and accurately predicted financial distress more than $90 \%$ of the time.

The purpose of this study was not to show that Altman $\mathrm{Z}$ is a final solution to predict financial distress, but a good tool for diagnosing future financial distress in companies.

The result " $Z$ " is effective; as it is useful in non-industrial public companies provided consideration of other important data at the same time. As with any financial instrument, Altman Z should contribute to decision making but not fully relied upon as a critical test of investment decisions.

Samarakoon and Hasan (2003) this study works on the capacity of three versions of Altman's Z-Score model of distress prediction developed in the U.S (Z, Z', and Z") to predict the corporate distress in the emerging market of Sri Lanka. The results of the paired t-test show that the mean differences in variables between the two groups 
are extremely significant. Values for variables X1, X2, X3, and X4* are below $1 \%$ while the p-values for X4 and $\mathrm{X} 5$ are below $2 \%$ level of significance. Table 4 provides the mean values and the paired test results for the two groups using financials in two years prior to distress. We observe significant difference in means for X3 at $1 \%$ and for X4* and X5 at 5\% level. Other variables are significant at 10\% level. The means in the distressed sample are lower than those in the non-distressed sample. Overall, these tests provide convincing evidence that on a unilabiate basis the specified variables are able to discriminate between distressed and non-distressed firms using financial statements prior to distress. The Z-Score classifies $90 \%$ of the distressed firms and $60 \%$ of the nondistressed firm accurately. The Z'-Score do a slightly better job of classifying the distressed firms correctly in that their success rate is $92 \%$ for distressed firms. Z"-model, which uses the book value based asset cushion and excludes the industry-sensitive asset turnover ratio, seems to be the best model for non-distressed firms with a level of accuracy of $69 \%$. The overall classification accuracy of the Z"-model is $81 \%$ and it is found to be the best model to predict the financial distress of Sri Lankan firms.

Pongsatat et al (2004) This paper reports the results of a research study examining the proportional ability of Ohlson's Logit model and Altman's four-variance model for predicting bankruptcy of big and small firms in the country Thailand. Hypothesis one reviews the comparative classification in predictive ability between Ohlson's model and Altman's four variable models of large asset firms. Ohlson's model reflected overall higher predictive accuracy for year one, year two, and year three, with an overall predictive accuracy of $69.64 \%$. In terms of bankrupt predictive ability of large asset firms Altman's model achieved higher accuracy for year one with an accuracy rate of $90.48 \%$ for year one and $100 \%$ accuracy rate for both years two and year three. However, with regard to non-bankrupt firms, Altman's model exhibited less predictive accuracy. Hypothesis two examined the comparative predictive ability between Ohlson's model and Altman's model to small asset firms. The results were similar to that found for large asset firms, that is, Ohlson's model was slightly higher in overall predictive accuracy than Altman's model. With regard to small asset bankrupt firms, Altman's model achieved higher accuracy for year one with a predictive accuracy rate of $94.87 \%$, year two with a predictive accuracy rate of $94.87 \%$ and year three with a predictive accuracy rate of $94.87 \%$. In the case of non-bankrupt predictive ability, Altman's model demonstrated less accuracy than Ohlson's model in each of the three years examined, however a test for difference indicated that these differences in hypothesis three were not significant. This implies that neither of the two models could be considered superior to the other for predicting bankruptcy of small asset Thai firms.

Altman et al (2010) the essence of this paper is to review the literature on the importance of the Altman Z-Score bankruptcy prediction model globally and its applications in Finance and related areas. It uses a large international sample of firms to assess the categorization performance of the model in bankruptcy and distressed firm prediction. It evaluates its performance in firms from 31 European and 3 non-European countries. Thus, the version of the Z- Score model developed by Altman in 1983 for private manufacturing and nonmanufacturing firms is used in our testing. The literature review shows that results for Z-Score Models have been uneven from fact that in some studies the model has performed very well. Results of analysis shows that the use of Emerging Market Z- score model and the Z-score model had clearly shown that, they can completely predict possible bankruptcy that may occur. In addition, they are effective when two years of information were used than one year.

Rascolean et al. (2012) All analysis models of the bankruptcy risk have at their basis a score function according to which it is determined with approximation whether the company would get bankruptcy or would have performing economic results, in a period immediately following the analysis. A Z-Score prediction system on Altman model was developed by using Lab View graphical program. The manner used is the statistical technique of analyzing the financial features of normally functioning societies and of the companies with difficulties in economic and financial administration. A company's capacity to adjust the obligations in time is estimated according to specific economic and financial conditions in which they operate. In close correlation with economic risk and financial risk falls to enterprises bankruptcy. Financial risk is a function of debt ratio; financial risk depends on the ratio between fixed costs and variable costs range. Knowledge of certain risk rates allows detection of an enterprise failure.

Kumar and Rao (2015) Abstract Credit estimation and bankruptcy prediction methods have utilized Altman's Zscore method for several years. A new nonlinear transformation procedure for building a log linear model for computing the Z-score is proposed. Based on the new Z-score (ZM) a new indexing measure is proposed by fitting the data to a P3 distribution and then obtaining the deviations of the given dataset from the standard normal using an equi-probability transformation. The multivariate discriminate analysis (MDA) for predicting 
the bankruptcy index has shown that the proposed methodology has given highest accuracy of $98.5 \%$, which is higher by $5 \%$ as compared with Altman's Z-score.

The classification accuracies of the transformed financial ratios in predicting the bankruptcy is around $93.7 \%$ as compared to $87.4 \%$ obtained by using the factors of Altman's procedure. The accuracies of the proposed method with P3 distribution was $92.2 \%$ where as a model with Pareto distribution resulted in an accuracy of $80 \%$.

Though the methodology is universal and serves as a generalized tool, there is an immense need to validate with global datasets. In addition, mutual interference among financial ratios is an important aspect that requires further investigation.

Ali and Abbas (2015) the essence of this research paper which deals with Altman Model in detail and describes the changes that the original Z-Score equation has fallen through. There is a discrepancy between the results of the three models in predicting bankruptcy for all companies because of the differences in percentages weight for each model. Most companies fall within the gray are, which indicates a weakness in performance and inability to make satisfactory profits for shareholders. Companies results reveal that most of them suffer from sever stagnation and that most of them do not distribute any profits at all or distribute very little profits. The companies representing the sample of the study seek to remain in the market as long as it can despite their weak performance because of its fear of bankruptcy and having to liquidate its activities.

Siddiqui (2012) this research paper summaries significant studies in the bankruptcy prediction area and provides a comparison of the different models, which are commonly used. The studies selected show that various financial information can be useful in predicting business failure. Most of the bankruptcy studies have used multiple discriminant analysis (MDA) statistical techniques to develop models and have included large and small firms, as well as private \& public firms. Dr Altman's model has been well researched and many pioneering studies have been done under his z-score yardstick. The significant changes done on the Altman equation has improved the predictability of bankruptcy. It started with an explanation of Business bankruptcy, or what does it mean for a business to become bankrupt. This discussion was followed by the various types of bankruptcy prediction model as relevant in today's economic scenarios. There are majorly five different types of bankruptcy prediction model. Multiple discriminant analysis is the crux of this research paper. Dr Altman's model is discussed in detail describing the changes occurring to the equation to reach a perfect prediction model.

Zubair et al. (2015) corporate failure prediction has become a very important issue in finance especially given the fact that so many researchers have given so many different types of prediction model. The multiple discriminant analysis seems to be the best model that achieves a very high result of accuracy. This study carried out its research for thirty-four companies grouping them into failed and no failed companies and paired them based on their size, industry and source in order to examine the relationships between the independent variables (WC/TA, RE/TA, EBIT/TA, MVE/TL\& S/TA) and the dependent variable (Z-score) in determining a company's failure and also to investigate whether or not all if all failed companies are listed under the PN-17 in bursa Malaysia. This research used quantitative method and random stratified sampling technique to choose the companies. The companies where analyzed using the descriptive analysis to show the difference between the failed and non-failed company means, which showed a significantly large difference between the two set of companies showing that the non-failed companies have positive mean while the failed companies showed negative means. The correlation analysis showed significant relationship between the independent variables (X1$\mathrm{X5}$ ) and the dependent variable (Z-score) in determining business failure. Similarly, the regression analysis carried out in this study showed accuracy of the Z-score between $85 \%$ and $99 \%$ accuracy levels which is in line with previous studies and their findings.

Makini (2015) this study was conducted with the objective of Altman's failure prediction model in predicting corporate financial distress in various companies listed in Kenya. Financial distress occurs as a result of economic distress, decline in performance and the poor management of companies. It is sometimes very difficult to ascertain these factors, which could indicate that a company is experiencing financial difficulties. One of the most commonly used tools by credit managers is financial statements and ratio analysis. This process serves to predict financial distress of a company. Some of the factors that are considered during analysis are profitability ratios, ratios relating to efficiency of asset management, risk, short term cash management and debt ratios as well as stock market data. By analyzing these ratios, however do not conclusively alert a credit granter that the company is in financial difficulties.

Chouhan et al. (2014) the major goal of this paper is to examine the Altman Z score. First, the Z score is calculated for 10 companies selected for this purpose for a period of 5 years each. The application of financial 
distress measurement literature flows into the international application of credit risk measurement to verify the robustness of such measures and techniques in different countries. This measure creates a significant impact on other finance research since its ability to test existing hypotheses with the new continuous variable may hold promise for a new stream of studies. Workable and promising topics with the new credit risk measure are not limited to the following examples. Our hypothesis concerning Altman's Z-score is based on arguments that the $\mathrm{Z}$-score have changed in the selected BSE companies, have found to be an unreached conclusion and all the companies are found to be in safe zone except HDFC Bank and BHEL. We can conclude that Altman's model still exists and used by the companies for measuring creditworthiness of the companies and it still remains promising but challenging.

Pang and Kogel (2013) This study reintroduces the famous discriminant functions from Edward Altman and Begley, Ming and Watts (BMW) that were used to predict bankruptcy. Discriminant functions for each separate industry should be used to predict bankruptcy. When using MDA, it is best to create separate discriminant functions using a recent sample from the industry in question. For example, it is not reasonable to assume that financial ratios of a steel company facing bankruptcy are the same as for a retail discount corporation. These two industries have different capital structures and different profitability averages. Separate discriminant scores should be developed for each industry. The analysis has concluded that the newly formulated discriminant functions in this study predicted bankruptcy and solvency for retail firms better than the Begley, Ming and Watts model and Altman's original and revised discriminant models.

Altman and Hotchkiss (2010) Distressed Firm and Bankruptcy prediction in an international context: a review and empirical analysis of Altman's Z-Score Model. The aim of this was to assess the performance of the Altman model presented in 1983; the origin of small and medium-sized industrial enterprises in the United States of America troubled ones. The model has been widely applied throughout the world to various industries Various size groups and private-equity companies, a modified version of the Altman model (1968) was developed for listed manufacturing companies and the model was modified to suit all non-Industrial Worldwide distributed the results of the Altman model as much as possible to non-adjusted companies Industrial.

The data used in this study were available to some 8 million companies covering this study More than $99 \%$ of the companies covered in the database were sample-owned industrial companies Limited liability and the total assets of more than one hundred thousand euros in addition to a minimum to the requirements to be met by the companies under consideration because the small percentages would cause a dispersion of values.

The sample was from various industries, and the most important results were that the model could be applied and proved successful in Bulgaria, Greece, Ireland, Norway, Slovenia, Spain, Ukraine and the United Kingdom Not effective in the case of liquidation and China needs special treatment but it was not effective in Denmark.

Zeytınoglu and Akarım (2013) examine the Money related Disappointment Expectation Utilizing Monetary Ratios an Exact Application on Istanbul Stock Trade. In this paper, they have built up a solid model which separates monetarily effective and unsuccessful firms in ISE All Area over the period 2009-2011 by utilizing discriminant research; utilizing Altman's 'Z score' to differentiate fruitful and unsuccessful firms. To look at the budgetary achievement of the companies, they have distinguished 20 key monetary ratios grouped under after subjects: liquidity, operation, obligation administration and benefit.

These high exactness ratios demonstrate that the created models for a long time are effective to decide the money related disappointment of the companies exchanged ISE. The factors utilized as a part of the review give valuable data identified with the money related circumstance of the companies in ISE. The models created by utilizing these factors are critical for budgetary experts, financial specialists and other company authorities.

Yasser and Al Mamun (2015) the aim of this study Corporate Failure Prediction of Public Listed Companies in Malaysia was to test the predictability of companies' regression in a standardized model by applying the Altman model for ease of comparisons. Moreover, for the ease of predicting failure when using many models, it is difficult to compare companies. Thus contributing to the disruption of the decision-making process. The sample was Malaysian companies listed on the Malaysian stock exchange during 2006-2010.The results in Ban concluded that the Altman model is good for predicting corporate stumbling and can be circulated to companies listed on the Sarawak Stock Exchange because of its success in forecasting. 


\section{Saudi literature review}

Najla (2003) Analytical study of some models to predict financial failure applied to Saudi companies the objective of this research to creating an accounting model can allow companies to predict financial failure before it occurs, so they can adopt appropriate measures to address this by correcting their financial structures or change their administrative systems.

The importance of this study Stems from the fact that Saudi Arabia has experienced recently some companies that have financial difficulties it has reduced their levels of activity and sometimes to announce their financial failure. A field study was conducted on Sample of Saudi companies for three consecutive years before

Financial failure. The sample consists of 10 successful companies Compared to 10 failed companies. With the Beefer sample application and Altman, in addition to the proposed model using Method of analyzing discrimination in the direct way. The most important the results were achieving a statistical model Different from traditional models that help to provide additional Information to the published financial statements in a simple manner, which helps to assess the performance of linear discrimination method. The proposed model proved superior to the three Years together before financial failure. The importance of applying multiple discrimination analysis a way to determine the extent of failure or success of companies Compared with traditional methods of financial analysis. In his vision of these results, the study recommended the need to take the following measures: Develop a comprehensive plan for the real application Cost systems to analyze deviations between schema and Actual, cost control components, production exploitation Capacity in the best possible way. Increase property rights and reducing the volume of loans. Use short-term financing Resources in the financing part of the assets, only provided that the remaining assets are financed from long-term financing sources.

Walid (2008) The problem of the study was the extent to which the economic units' predictability could be expected before they occurred through the use of the Altman model based on the published financial statements, and whether it relied on identifying troubled companies before they failed. The aim of the study was to measure the appropriateness of certain financial ratios derived from the published financial statements by using the $\mathrm{z}$ score (Altman) model to predict the default of companies operating in Saudi Arabia a year or two before the default. This study also includes three hypotheses to test the extent to which financial institutions are financially faltering in the Kingdom of Saudi Arabia before it occurs:

- There is a correlation between the financial stumbling of companies operating in the Kingdom and the $\mathrm{Z}$ score in the Altman model Calculated a year before financial stumbling.

- There is a weaker correlation between the financial stumbling of companies operating in the Kingdom and the $\mathrm{Z}$ score in the Altman model calculated two years before the financial stumbling of the correlation between the financial stumbling of companies operating in the Kingdom and the $\mathrm{Z}$ calculated a year before the financial downturn.

The statistical model (Pobit Model for Panel Data) was applied to the data of 200 companies over a period of 5 years in the period 1999-2003. Five financial ratios were used for the Altman model, the ratio of working capital to total assets, profit ratio,

Total Assets, Ratio of Income before Interest and Gross Assets to Total Assets

The market value of equity shares to total liabilities and the ratio of sales to total assets.

The study concluded that there was a strong correlation between $\mathrm{Z}$ scores calculated one year ago, Two years from the date of default and between the Saudi companies' results. It also found that there was no significant difference between $\mathrm{Z}$ scores calculated one year ago and $\mathrm{Z}$ scores calculated two years ago. Compared to the financial stumbling of companies two years before it happened.

\section{What distinguishes this study from the previous studies}

Most of these studies focused on the use of financial ratios to predict organizations shortening From various levels and through the development of financial ratios models to predict the failure of organizations Most of the previous studies have used many work analyzes, as well as many of them Economic sectors conducted in different places of the world note that these studies Differed among themselves about the results reached as a natural result of different times The places where they were made, What distinguishes this study is that it will apply the Altman model to troubled Saudi companies And successful companies listed in the Tadawul market and modernity Search covering the 2013-2016 time period.

\section{Methodology}

\section{Type of study}

In this research, a distinction analysis was used, which is one of the most prominent statistical types of prediction. Discriminatory analysis is one of the most widely used methods of studying financial failure (Altman, 1968). 
Discriminant capacity can be portrayed as takes after: $\mathrm{Z}=\alpha+\mathrm{b} 1 \mathrm{X} 1+\mathrm{b} 2 \mathrm{X} 2+\ldots \ldots+\mathrm{bnXn}$

In the condition;

"Z" discriminant score,

" $\alpha$ " constant,

"b1, b2, ... bn discriminant coefficients of independent variables

"X1, X2,.... Xn" " independent variables

$\mathrm{n}=$ the number of independent variables.

\section{Numerical Model}

The model utilized as a part of this review is given as "Z" with the first Z-score equation given as takes after:

\section{$\mathrm{Z}=1.2 \mathrm{X} 1+1.4 \mathrm{X} 2+3.3 \mathrm{X} 3+0.6 \mathrm{X} 4+0.999 \times 5 \quad$ Where:}

$\mathrm{X} 1=$ Working Capital to Total Assets Ratio.

$\mathrm{X} 2=$ Retained Earnings to Total Assets Ratio.

X3 = Earnings before Interest and Taxes to Total Assets Ratio.

X4 $=$ Value of Equity to Total Liabilities Ratio.

$\mathrm{X} 5=$ Gross Earnings to Total Assets Ratio.

After the calculations, a choice control to separate among the distressed companies and non-distressed companies are as follows:

\begin{tabular}{|l|l|}
\hline ZSCORE VALUE & IMPLICATION \\
\hline Below 1.81 & Weak Performance/Bankruptcy Zone \\
\hline $1.81-2.99$ & Healthy Performance \\
\hline Above 2.99 & Very Healthy/Sound Performance \\
\hline
\end{tabular}

(Source: Altman, 1968)

\section{Hypothesis}

Test the null hypothesis that:

$\mathrm{H} 0$ : financial ratios are an effective indicator of bankruptcy prediction.

Against the alternative hypothesis that:

H1: Financial ratios are not an effective estimate of bankruptcy prediction.

\section{Data Method}

The data studied comprises of the annual financial statements of two non-failed firms (Al Marai and Saudi Basic Industries Corp) and two failed firms (Bishah Agriculture Development and Al Baha Investment and Development) randomly selected for Four years spanning the period between 2013 - 2016. Financial statements are available for the general public in (TADAWUL).

\section{The Sample}

\begin{tabular}{|l|l|}
\hline non-failing firm & failing firm \\
\hline Al Marai (2280) & Bishah Agriculture Development (6080) \\
\hline Saudi Basic Industries Corp (2010) & Al Baha Investment and Development (4130) \\
\hline
\end{tabular}

* On Saudi Stock Exchange (TADAWUL).

\section{Statistical analysis technique}

The Different Discriminant Analysis Model (Multi-Variate Research of Z-scores). 


\section{Interpretation of Results}

\section{Descriptive Analyses:}

Table1: Al Marai Financial Statements:

\begin{tabular}{|l|l|l|l|l|}
\hline balance sheet & $\mathbf{2 0 1 3}$ & $\mathbf{2 0 1 4}$ & $\mathbf{2 0 1 5}$ & $\mathbf{2 0 1 6}$ \\
\hline current assets & $2,802,930$ & $2,142,522$ & $3,319,324$ & $2,136,173$ \\
\hline total assets & $23,279,970$ & $23,948,915$ & $27,371,035$ & $29,022,740$ \\
\hline current liabilities & $3,720,463$ & $4,042,934$ & $4,806,636$ & $4,793,320$ \\
\hline shareholders' equity & $10,142,470$ & $10,886,852$ & $12,058,445$ & $13,035,593$ \\
\hline total liabilities and equity & $23,279,970$ & $23,948,915$ & $27,371,035$ & $29,022,740$ \\
\hline total liabilities & $13,137,500$ & $13,062,063$ & $15,312,590$ & $15,987,147$ \\
\hline statement of income & & & & \\
\hline total income & $3,951,846$ & $4,555,932$ & $5,283,263$ & $5,833,612$ \\
\hline net income b z & $1,544,192$ & $1,745,408$ & $1,981,426$ & $2,154,830$ \\
\hline
\end{tabular}

\begin{tabular}{|l|l|l|l|l|l|l|l|}
\hline coefficient of variation & median & range & $\min$ & $\max$ & standard deviation & sum & Mean \\
\hline 22.0145371 & $2,472,726$ & $1,183,151$ & $2,136,173$ & $3,319,324$ & 572430.195 & $10,400,949$ & $2,600,237$ \\
\hline 10.5918095 & $25,659,975$ & $5,742,770$ & $23,279,970$ & $29,022,740$ & 2743878.68 & $103,622,660$ & $25,905,665$ \\
\hline 12.5850467 & $4,418,127$ & $1,086,173$ & $3,720,463$ & $4,806,636$ & 546296.522 & $17,363,353$ & $4,340,838$ \\
\hline 11.0664433 & $11,472,649$ & $2,893,123$ & $10,142,470$ & $13,035,593$ & 1276053.87 & $46,123,360$ & $11,530,840$ \\
\hline 10.5918095 & $25,659,975$ & $5,742,770$ & $23,279,970$ & $29,022,740$ & 2743878.68 & $103,622,660$ & $25,905,665$ \\
\hline 10.4219953 & $14,225,045$ & $2,925,084$ & $13,062,063$ & $15,987,147$ & 1498143.59 & $57,499,300$ & $14,374,825$ \\
\hline & & & & & & & \\
\hline 16.790339 & $4,919,598$ & $1,881,766$ & $3,951,846$ & $5,833,612$ & 823761.444 & $19,624,653$ & $4,906,163$ \\
\hline 14.4029453 & $1,863,417$ & 610,638 & $1,544,192$ & $2,154,830$ & 267385.495 & $7,425,856$ & $1,856,464$ \\
\hline
\end{tabular}

Almarai is considered a stable financial company considering net income. When to look at the balance sheet, Almarai company is looking to expand because it is increasing the value. The total of current assets for Almarai for four years is 10,400949 , which is a weak amount if we want to repay the current liabilities. The oscillation between the minimal value and the maximal value is not big.

Table2: Saudi Basic Industries Corp Financial Statements:

\begin{tabular}{|l|l|l|l|l|}
\hline balance sheet & $\mathbf{2 0 1 3}$ & $\mathbf{2 0 1 4}$ & $\mathbf{2 0 1 5}$ & $\mathbf{2 0 1 6}$ \\
\hline current assets & $102,410,376$ & $103,077,416$ & $92,426,560$ & $85,385,448$ \\
\hline total assets & $33,070,569$ & $340,041,079$ & $328,219,154$ & $361,892,858$ \\
\hline current liabilities & $44,466,113$ & $43,435,824$ & $42,604,725$ & $41,110,794$ \\
\hline shareholders' equity & $156,271,417$ & $162,532,570$ & $161,924,049$ & $163,047,895$ \\
\hline total liabilities and equity & $339,070,569$ & $340,041,079$ & 328219154 & $316,892,858$ \\
\hline total liabilities & $182,799,152$ & $177,508,509$ & $166,295,105$ & $153,844,963$ \\
\hline statement of income & & & & \\
\hline total income & $55,344,363$ & $51,650,150$ & $43,027,760$ & $40,910,071$ \\
\hline net income b z & $27,578,382$ & $25,447,114$ & $20,868,690$ & $20,838,843$ \\
\hline
\end{tabular}




\begin{tabular}{|l|l|l|l|l|l|l|l|}
\hline $\begin{array}{l}\text { coefficient of } \\
\text { variation }\end{array}$ & median & range & min & max & $\begin{array}{l}\text { standard } \\
\text { deviation }\end{array}$ & mean & sum \\
\hline 8.865190493 & $97,418,468$ & $17,691,968$ & $85,385,448$ & $103,077,416$ & 8495064.357 & $95,824,950$ & $383,299,800$ \\
\hline 4.123443991 & $339,555,824$ & $33,673,704$ & $328,219,154$ & $361,892,858$ & 14114792.68 & $342,305,915$ & $1,369,223,660$ \\
\hline 3.303933107 & $43,020,275$ & $3,355,319$ & $41,110,794$ & $44,466,113$ & 1417531.487 & $42,904,364$ & $171,617,456$ \\
\hline 1.956412138 & $162,228,310$ & $6,776,478$ & $156,271,417$ & $163,047,895$ & 3148727.613 & $160,943,983$ & $643,775,931$ \\
\hline 3.279431769 & $333,644,862$ & $23,148,221$ & $316,892,858$ & $340,041,079$ & 10856752.85 & $331,055,915$ & $1,324,223,660$ \\
\hline 7.549959261 & $171,901,807$ & $28,954,189$ & $153,844,963$ & $182,799,152$ & 12843381.58 & $170,111,932$ & $680,447,729$ \\
\hline & & & & & & & \\
\hline 14.41172412 & $47,338,955$ & $14,434,292$ & $40,910,071$ & $55,344,363$ & 6879160.666 & $47,733,086$ & $190,932,344$ \\
\hline 14.27636286 & $23,157,902$ & $6,739,539$ & $20,838,843$ & $27,578,382$ & 3381107.742 & $23,683,257$ & $94,733,029$ \\
\hline
\end{tabular}

Saudi Basic Industries Corp is a strong company in the Saudi stock market. Note that the value of the company decreases during the four years and this confirms that the company limits its expansion. The Company commits the current liabilities of traded assets well. Statement of income decreased significantly as total income for the year 2013: 55344363 and then decreased to 40910071 in 2016.

Table3: Bishah Agriculture Development Financial Statements:

\begin{tabular}{|l|l|l|l|l|}
\hline balance sheet & $\mathbf{2 0 1 3}$ & $\mathbf{2 0 1 4}$ & $\mathbf{2 0 1 5}$ & $\mathbf{2 0 1 6}$ \\
\hline current assets & 9,041 & 1,898 & 1,213 & 882 \\
\hline total assets & 44,598 & 44,313 & 42,370 & 40,399 \\
\hline current liabilities & 45,178 & 44,903 & 45,139 & 45,424 \\
\hline shareholders' equity & $-2,219$ & $-1,966$ & $-3,445$ & $-5,385$ \\
\hline total liabilities and equity & 44,598 & 44,313 & 42,370 & 40,399 \\
\hline total liabilities & 46,817 & 46,279 & 45,815 & 45,784 \\
\hline statement of income & & & & \\
\hline total income & 85 & -110 & 11 & 86 \\
\hline net income b z & -961 & $-1,293$ & $-1,474$ & $-2,431$ \\
\hline
\end{tabular}

\begin{tabular}{|l|l|l|l|l|l|l|l|}
\hline $\begin{array}{l}\text { coefficient of } \\
\text { variation }\end{array}$ & median & range & min & max & $\begin{array}{l}\text { standard } \\
\text { deviation }\end{array}$ & variance & mean \\
\hline 119.0163 & 1,556 & 8,159 & 882 & 9,041 & 3878.148 & 15040030 & 3,259 \\
\hline 4.544645 & 43,342 & 4,199 & 40,399 & 44,598 & 1950.562 & 3804691 & 42,920 \\
\hline 0.472337 & 45,159 & 521 & 44,903 & 45,424 & 213.312 & 45502 & 45,161 \\
\hline-47.9677 & $-2,832$ & 3,419 & $-5,385$ & $-1,966$ & 1560.749 & 2435937 & $-3,254$ \\
\hline 4.544645 & 43,342 & 4,199 & 40,399 & 44,598 & 1950.562 & 3804691 & 42,920 \\
\hline
\end{tabular}




\begin{tabular}{|l|l|l|l|l|l|l|l|}
\hline 1.050216 & 46,047 & 1,033 & 45,784 & 46,817 & 484.9243 & 235151.6 & 46,174 \\
\hline & & & & & & & \\
\hline 512.6587 & 48 & 196 & -110 & 86 & 92.27856 & 8515.333 & 18 \\
\hline-40.9807 & $-1,384$ & 1,470 & $-2,431$ & -961 & 631.001 & 398162.3 & $-1,540$ \\
\hline
\end{tabular}

Bishah Agriculture Development is a weak company in the Saudi market. It appears that it is suffering from huge financial problems as its current assets are not enough to settle its current liabilities. We also note that net income is negative so the company is on its way to liquidation.

Table4: A1 Baha Investment and Development Financial Statements:

\begin{tabular}{|l|l|l|l|l|}
\hline balance sheet & $\mathbf{2 0 1 3}$ & $\mathbf{2 0 1 4}$ & $\mathbf{2 0 1 5}$ & $\mathbf{2 0 1 6}$ \\
\hline current assets & 28,021 & 25,563 & 17,387 & 17,849 \\
\hline total assets & 100,959 & 97,635 & 98,460 & 98,922 \\
\hline current liabilities & 91,926 & 93,205 & 93,963 & 94,881 \\
\hline shareholders' equity & 7,956 & 3,862 & 3,929 & 3,957 \\
\hline total liabilities and equity & 100,959 & 97,695 & 98,460 & 98,922 \\
\hline total liabilities & 93,003 & 93,833 & 94,531 & 94,965 \\
\hline statement of income & & & & \\
\hline total income & - & - & 609 & 610 \\
\hline net income b z & $-78,190$ & $-4,014$ & 67 & 29 \\
\hline
\end{tabular}

\begin{tabular}{|l|l|l|l|l|l|l|l|}
\hline $\begin{array}{l}\text { coefficient of } \\
\text { variation }\end{array}$ & median & range & min & max & $\begin{array}{l}\text { standard } \\
\text { deviation }\end{array}$ & variance & mean \\
\hline 24.29241 & 21,706 & 10,634 & 17,387 & 28,021 & 5394.129 & 29096627 & 22,205 \\
\hline 1.4284 & 98,691 & 3,324 & 97,635 & 100,959 & 1414.03 & 1999482 & 98,994 \\
\hline 1.336756 & 93,584 & 2,955 & 91,926 & 94,881 & 1249.783 & 1561958 & 93,494 \\
\hline 41.01488 & 3,943 & 4,094 & 3,862 & 7,956 & 2020.393 & 4081989 & 4,926 \\
\hline 1.408962 & 98,691 & 3,264 & 97,695 & 100,959 & 1394.999 & 1946022 & 99,009 \\
\hline 0.911762 & 94,182 & 1,962 & 93,003 & 94,965 & 857.8127 & 735842.7 & 94,083 \\
\hline & & & & & & & \\
\hline 0.116014 & 610 & 1 & 609 & 610 & 0.707107 & 0.5 & 610 \\
\hline-187.507 & $-1,993$ & 78,257 & $-78,190$ & 67 & 38489.66 & $1.48 \mathrm{E}+09$ & $-20,527$ \\
\hline
\end{tabular}

Al Baha Investment and Development is a weak company in the Saudi market. It is clear from its financial statements that it is heading towards bankruptcy. As its trading commitment is very huge compared to the liquidity of the company. The weakness of the income statement is evident, and even if it made profits for the last two years, profits remain negligible due to its huge commitment. 


\subsection{Statistical Analyses:}

\begin{tabular}{|l|l|l|l|l|l|l|}
\hline A1 Marai & $\mathrm{x} 1$ & $\mathrm{x} 2$ & $\mathrm{x} 3$ & $\mathrm{x} 4$ & $\mathrm{x} 5$ & $\mathrm{Z}$ \\
\hline 2013 & -0.039413 & 0.43567367 & 0.066331357 & 0.43567367 & 0.16975305 & 1.21252855 \\
\hline 2014 & -0.0793527 & 0.45458644 & 0.072880462 & 0.45458644 & 0.19023542 & 1.24450031 \\
\hline 2015 & -0.0543389 & 0.44055495 & 0.072391344 & 0.44055495 & 0.19302387 & 1.2476255 \\
\hline 2016 & -0.091554 & 0.44915101 & 0.074246263 & 0.44915101 & 0.20100142 & 1.23425035 \\
\hline
\end{tabular}

\begin{tabular}{|l|l|l|l|l|l|l|}
\hline $\begin{array}{l}\text { Saudi Basic } \\
\text { Industries Corp }\end{array}$ & $\mathrm{x} 1$ & $\mathrm{x} 2$ & $\mathrm{x} 3$ & $\mathrm{x} 4$ & $\mathrm{x} 5$ & $\mathrm{z}$ \\
\hline 2013 & 0.170891455 & 0.46088169 & 0.081335228 & 0.46088169 & 0.16322373 & 1.558299885 \\
\hline 2014 & 0.175395256 & 0.477979221 & 0.074835411 & 0.477979221 & 0.151893854 & 1.565131566 \\
\hline 2015 & 0.151794417 & 0.493341254 & 0.063581573 & 0.493341254 & 0.131094604 & 1.509618507 \\
\hline 2016 & 0.122341884 & 0.450541898 & 0.057582908 & 0.514520573 & 0.113044704 & 1.389236516 \\
\hline
\end{tabular}

\begin{tabular}{|l|l|l|l|l|l|l|}
\hline Bishah Agriculture Development & $\mathrm{x} 1$ & $\mathrm{x} 2$ & $\mathrm{x} 3$ & $\mathrm{x} 4$ & $\mathrm{x} 5$ & $\mathrm{z}$ \\
\hline 2013 & -0.81028 & -0.04976 & -0.021548051 & -0.04976 & 0.001906 & -1.14106 \\
\hline 2014 & -0.97048 & -0.04437 & -0.029178796 & -0.04437 & -0.00248 & -1.35208 \\
\hline 2015 & -1.03672 & -0.08131 & -0.034788766 & -0.08131 & 0.00026 & -1.52123 \\
\hline 2016 & -1.10255 & -0.1333 & -0.060174757 & -0.1333 & 0.002129 & -1.7861 \\
\hline
\end{tabular}

\begin{tabular}{|l|l|l|l|l|l|l|}
\hline A1 Baha Investment and Development & $\mathrm{x} 1$ & $\mathrm{x} 2$ & $\mathrm{x} 3$ & $\mathrm{x} 4$ & $\mathrm{x} 5$ & $\mathrm{z}$ \\
\hline 2013 & -0.63298 & 0.078804 & -0.774472806 & 0.078804 & 0 & -3.1577 \\
\hline 2014 & -0.6928 & 0.039555 & -0.041112306 & 0.039531 & 0 & -0.8879 \\
\hline 2015 & -0.77774 & 0.039905 & 0.000680479 & 0.039905 & 0.006185 & -0.8451 \\
\hline 2016 & -0.77871 & 0.040001 & 0.00029316 & 0.040001 & 0.006166 & -0.8473 \\
\hline
\end{tabular}

Altman postulated that companies with a Z-Score $<1.8$ were likely to experience bankruptcy, companies with a Z-score 1.8 to 2.99 were in a zone of ignorance, or a grey zone. Companies with a Z-score of $>2.99$ were likely to be financially sound. However, there is no single formula that has the power to predict the future; ZScore users should look at the trend of the business over time as they interpret the score rather than just looking at the score itself.

Almarai has grown in $\mathrm{Z}$ value for 2014 and 2015 and has returned to stability in 2016 and shows that Almarai is in good condition despite being classified in the gray zone for the Altman model.

In view of SABIC, we note that the value of $Z$ has shrunk and we have said in advance that the company to reduce its activity and limit its expansion, despite the decline in value of Z, SABIC is strong in the Saudi market. 
We note that Bishah is showing a negative $Z$ value and this show that the company is in a very bad position. The value of $\mathrm{Z}$ decreases further, which tells the company that it must take the necessary action to liquidate the company.

Al-Baha is in a bad position in the Saudi market and this is clear from the negative $\mathrm{Z}$ value. This bad year for the company had to save the financial position of the company earlier before it reached this stage.

In the end, it is clear from the results of the study that the value of $\mathrm{Z}$ is not only seen, but also the stability of $\mathrm{Z}$ value. In addition, it does not rely on the value of $Z$ to make a decision, but the company is analysed in view of other companies in the market. Also compared with it over the years.

I suggest that the value of the $\mathrm{Z}$ value in the Saudi market be examined further. I find that the $\mathrm{Z}$ value of 2.99 is high given the level of large companies in the Saudi market, but 1.2 and above is evidence that the company is stable and financially well.

\section{Summary and Conclusions}

Summing up the study of bankruptcy prediction model, it is concluded that this model is a very useful tool for analysts, credit institutions and administrations of the same companies to assess their performance.

The most important result of the research is that the Liquidity, profitability, operating efficiency and total assets turnover (which are the key variables in the Altman's Z score) are very potent tools.

In this study, we explained the importance of the liquidity ratio as well as the remaining profits, in addition to considering the efficiency of capital and efficiency of operation. These are the most important financial ratios when we would like to predict bankruptcy in the Saudi financial market and we should also look at the general financial analysis of the company. When we talk about the efficiency of capital, we mean how the manager manages the assets of the company. The ratio indicates that capital efficiency is high indicates that the company works better. In other words, the manager manages assets efficiently. The general liquidity ratio refers to the ability of the Company to repay short-term creditors out of the total cash available to the Company. When the result shows a high percentage, the Company is in a position to pay its obligations. Retained earnings are the percentage of net profits that have not been paid as "retained" earnings to be reinvested in the company or used to repay future debts.

When we talk about the ratio of retained earnings to total assets, how much does the company rely on debt or leverage. Here, the lower the ratio, the more the company will finance its assets by borrowing instead of the profits realized, putting the company at risk of bankruptcy if the company cannot meet its debt obligations.

When we look at the ratio of total liability and equity to ordinary shares and preferred shares. The higher the percentage, the better the financial management of the company. Therefore, the company must keep all the variables in high proportion in order to prevent bankruptcy that is likely to affect the company.

Altman's Score-Z model is capable of detecting financial failure and bankruptcy before it is sufficiently timeconsuming to enable organizations and beneficiaries to take corrective action in a timely manner.

The results of the analysis of the main financial indicators of the model showed that there was a weakness in the performance of the organizations surveyed through the weak indicators that emerged, confirming their approach to the bankruptcy area, as these organizations did not take the necessary steps to rectify their course.

The efficiency of management in using the resources available to the organization and how to exploit its assets, its ability to optimize the use of these assets, maximize the volume of sales, and how to deal with its creditors are the ones that avoid financial risk and thus avoid bankruptcy.

The use of the Altman Score-Z model to predict bankruptcy enables the organization and investors to assess investment opportunities as they can identify and dispose of the wrong business before they suffer more losses and lead the organization to better opportunities.

The Score-Z model helps to illustrate the current and future financial situation in which organizations can be forecasted, providing useful information to stakeholders on the reality of Saudi organizations. 
In conclusion, we can say that the model that was studied provides a measure of the financial situation of the company and a warning in advance, to remedy the situation. It is also a good tool investor can use to monitor the stability of their investments. The model is generally good and recommended but needs more studies and greater application in Saudi Arabia.

\section{Recommendation}

Based on the study findings, the following recommendations were made:

1. Urge investors, financial analysts and auditors to use the Altman model to know the financial position of companies and make appropriate investment decisions.

2. The need to update forecasting models for financial failure according to the changes that occur.

3. The need to identify the cause of poor performance of many companies and take steps to correct the performance of these companies because the increasing weakness in the performance of companies will be

Affects the national economy.

4. Urge official government bodies, trade unions and federations to hold on-going seminars and discussions for employers to raise awareness of the concept and patterns of default and their impact on accounting companies and financiers on the other hand to train them on how to use ratios to predict the financial position of the company.

5. Need to urge professional organizations to issue a standard on failure and forecasting to guide companies to help them maintain their work and take precautions to avoid failure.

6 - The need to study the causes of financial stumbling in the Saudi stock companies, and make the necessary decisions to reduce the phenomenon of default and avoid the arrival of companies to the stage of bankruptcy.

7. Emphasis on disclosure and transparency in financial statements, and the need to pay attention to its accuracy to indicate financial stumbling.

\section{References}

Ali, M.F.A. and Abbas, A.A., (2015). Companies Bankruptcy Prediction by Using Altman Models and Comparing Them. Hypothesis, 6(14).

Altman, E.I., (1968). Financial ratios, discriminant analysis and the prediction of corporate bankruptcy. The journal of finance, 23(4), pp.589-609.

Altman, E.I. and Hotchkiss, E., (2010). Corporate financial distress and bankruptcy: Predict and avoid bankruptcy, analyse and invest in distressed debt (Vol. 289). John Wiley \& Sons.

Altman, E., Iwanicz-Drozdowska, M., Laitinen, E. and Suvas, A., (2014). Distressed Firm and Bankruptcy Prediction in an International Context: A Review and Empirical Analysis of Altman's Z-Score Model. In 4th Annual Conference on the Department of Finance, University of Lagos.

Al-Shabani W (2008) The Role of Accounting Information in Predicting the Financial Impairment of Saudi Companies, King Saud University, College of Administrative Sciences, Volume 20, Number 2

Chouhan, V., Chandra, B. and Goswami, S., (2014). Predicting financial stability of select BSE companies revisiting Altman Z score. International Letters of Social and Humanistic Sciences, 15(2), pp.92-105.

Hayes, S.K., Hodge, K.A. and Hughes, L.W., (2010). A study of the efficacy of Altman's Z to predict bankruptcy of specialty retail firms doing business in contemporary times. Economics \& Business Journal: Inquiries \& Perspectives, 3(1), pp.130-134.

Hu, G., \& Zhang, X. (2009). Study on improving Z-score model based on the logistic model: evidence from listed companies in China. In Information Management, Innovation Management and Industrial Engineering, 2009 International Conference on (Vol. 2, pp. 240-244). IEEE. 
Kumar, M.N. and Rao, V.S.H., (2015). A new methodology for estimating internal credit risk and bankruptcy prediction under Basel II Regime. Computational Economics, 46(1), pp.83-102.

Makini, P.A., (2015). Validity of Altman's Z-score Model in Predicting Financial Distress of Listed Companies at the Nairobi Securities Exchange. Unpublished MBA project, University of Nairobi.

Miller, W., (2009). Comparing models of corporate bankruptcy prediction: Distance to default vs. Z-score. International Journal of Finance and Accounting, 2(6), pp. 319-325.

Meeampol, S., Lerskullawat, P., Wongsorntham, A., Srinammuang, P., Rodpetch, V. and Noonoi, R., (2014), June. Applying emerging market Z-score model to predict bankruptcy: A case study of listed companies in the stock exchange of Thailand (Set). In International Conference (pp. 25-27).

Najla I. A. (2003) Analytical study for the models of knowledge of financial failure applied to companies in Saudi Arabia

Pongsatat, S., Ramage, J. and Lawrence, H., (2004). Bankruptcy prediction for large and small firms in Asia: a comparison of Ohlson and Altman. Journal of Accounting and Corporate Governance, 1(2), pp.1-13.

Pang, J. and Kogel, M., (2013). Retail bankruptcy prediction. Australian Journal of Basic and Applied Sciences, 5(8), 930-938.

RajapakshaR M and YapaR D (2016). Relationship between Financial Ratios \& Share Prices and Prediction of Financial Failure: Evidence from Sri Lanka.

Răscolean, I., Dobra, R. and Slusariuc, G.C., (2012). Predictive analysis software for modelling the Altman Zscore financial distress status of companies. of the university of petrosani economics, $\mathrm{p} 231$.

Siddiqui, S.A., (2012). Business Bankruptcy Prediction Models: A Significant Study of the Altman's Z-Score Model. International Journal of Business and Social Research, 5(3), pp.41-56.

Samarakoon, L. and Hasan, T., (2003). Altman's Z-Score models of predicting corporate distress: Evidence from the emerging Sri Lankan stock market.

Yap, B. C. F., Helmi, M. H. M., Munuswamy, S., \& Yap, J. R. (2011). The predictive abilities of financial ratios in predicting company failure in Malaysia using a Classic Univariate approach. Australian Journal of Basic and Applied Sciences, 5(8), 930-938.

Yasser, Q.R. and Al Mamun, A., (2015). Corporate failure prediction of public listed companies in Malaysia. Evropejskij Issledovatel', 91(2), pp.114-126.

Zeytinoglu, E., \&Akarim, Y. D. (2013). Financial failure prediction using financial ratios: An empirical application on Istanbul Stock Exchange. Journal of Applied Finance and Banking, 3(3), 107.

Zubair, H, Ishioma, O \& Abdul, B, (2015). Prediction of damage using the Altman Z-Skur model: State of public companies registered in Malaysia. 